\title{
THE SIXTH SEAL IN REVELATION 6:12-17
}

\author{
P.G.R. de Villiers ${ }^{1}$
}

\begin{abstract}
This article illustrates the relevance of a close reading of the text in the ongoing work of New Testament as a discipline by means of Revelation 6:12-17. In an introduction the nature and role of a close reading in Biblical Studies is briefly outlined. A second part analyses the form of the sixth seal and indicates what and how literary techniques were used to compose the text. These are then in turn investigated to explain the meaning and function of this seal within the communication setting in which it originated and for which it was composed.
\end{abstract}

\section{INTRODUCTION}

New Testament as a discipline is in the first instance a text-focused subject. It is the only one of theological disciplines that has a point beyond which it cannot move. That point is the text. This is a simple truth with many implications. Often the text is a victim rather than the focus of scholarly research, especially when it is investigated in an illegitimate manner or where its integrity is not respected. Too often the text is "used" to determine what "really happened" or what was "taught" without serious attention to the text itself. Or, alternatively, too often the interpretations of the text rather than the text itself, determine what happens in scholarship. It happens easily that we know much about the text and we can cite so many interpretations of the text, without a proper knowledge of or understanding of the text as text.

One of the formative roots of modern Biblical scholarship can be traced to the Renaissance which was such a rejuvenating force because of its movement ad fontes. The original sources were rediscovered and documented. Biblical languages as an empowering tool were once again studied (cf. De Villiers 2001). This studia bumanitatis generated much new knowledge and brought about valuable new life in the history of the church and theology. The "dark" Middle Ages with a

1 Prof. P.G.R. de Villiers, Research Fellow, Department of New Testament, Faculty of Theology, University of the Free State, P.O. Box 339, Bloemfontein 9300. E-mail: pgdevilliers@mweb.co.za 
church that valued Latin more than Greek and Hebrew and with theologians that knew more of philosophy than of the text, ${ }^{2}$ represent a tragic example of what can go wrong when the text as the heart of theological and Biblical studies is neglected.

A survey of the massive amounts of publications in New Testament studies shows how many new insights are being created. Real progress has been made in the modern phase of Biblical Studies since the Renaissance and Enlightenment. Yet, paradoxically, these many new books illustrate exactly the tentative nature of research as it keeps on debating issues and the ongoing need to study the texts carefully. Though they develop new insights, they also continuously deconstruct existing, even sacrosanct ones, about the text. Text and interpretation are involved in a process of clarification and debate, so that there is no indication that we have arrived at a final stage of scholarship. The point is not whether new work on the text can be done. It is more a matter of how it will be done.

A case in point is the study of the text of Revelation that has benefited much from the study of linguistics and of rhetoric in recent years, but that can still benefit from a close reading. This article will illustrate this through a close reading that will focus on the compositional skills of the author of Revelation. A careful author is at work on several levels in the text. From micro-level to meso-level through to macro-level, as will be pointed out in more detail below, fascinating patterns can be detected. ${ }^{3}$

2 Erasmus, who may be called a founding father of modern historical research, at some stage became concerned about the way in which Renaissance scholars lapsed into what he considered a neo-paganism (De Villiers 2002:39). In this sense he confirmed the special nature and claims of the Biblical texts as focal point of research. He sought to promote a deepening of the scholar's commitment to Christ as purpose of the so famous studia humanitatis. One of the most respected contemporary historians remarks that this study was to him merely "beguiling, worthless, indeed dangerous unless infused with a thirst for Christian truth... in non-speculative, moralistic terms" (Israel 1998:45).

3 Since one can assume that an intelligent and normal author will be consistent in his thought, it is to be expected that what happens on micro-level, will also take place on meso- and macro-level. In other words, it is to be expected that the author would structure his work in the smaller units in the same manner in which he would group larger units or the text as a whole. 
The sixth seal in Revelation 6 is one of the prime examples of the compositional skills of the author of Revelation. In the following essay this seal will be investigated in order to show how new insights can be generated when the text itself is heard and when methods that are in line with Biblical studies as a textual discipline, are applied to it.

\section{THE SIXTH SEAL}

The sixth seal is, first of all, more generally part of the seven seals about four horses and their riders (seals one to four). It is more specifically part of the last three seals where it fits between seals five and seven - about a group of slain believers under the altar. The first four refer to disasters that strike the earth and that creates the scenario described in the last three seals, where the martyrdom of the believers and the judgment on the evil forces and their human following are depicted.

The seals have a pattern of $4+3$, but this can be formulated more specifically as $3+1+3$. The two groups of three (1-3 and 5-7), in turn, display a sandwich effect in which the first and third element frames the middle element. In addition the fourth seal is framed by the first and the last three seals. The fourth seal forms the heart of the series — depicting death and Hades as the prime forces of evil. The fourth seal identifies the forces of evil that are at work in the persecution of the church and the destruction of God's creation. They stand at the beginning of the assault on this world (Revelation 6), but they are also the last to be removed from the scene (after the dragon, the two beasts and the whore; cf. Rev. 20:14). As such, the fourth seal plays a seminal role in the series of seven seals. ${ }^{4}$

Even though the fourth seal is so striking, it is the sixth seal that really catches the eye. The following reasons can be given for this statement: It is, firstly, the longest of the seven seals. It is, secondly, the penultimate seal — which in apocalyptic literature is quite significant. Thirdly, the sixth seal is the middle of the last three seals. It is framed by seals 5 and 7 that are mutually related because both

4 Cf. the extensive discussion of the composition of the seven seals in De Villiers (2004). 
refer to the saints who have been slaughtered and share prominent motifs like the altar. The contents, fourthly, also draw attention to this seal. There is firstly a section on the judgment of the world and a second, supplementary section on the church. In many commentaries this second section is regarded as an intercalation because its contents are so seemingly different. Though this part forms a unit on its own and offers a different perspective on events, it should be read as complementing the judgment section and not separated too strongly from it. This is clear in the light of the fact that it provides the answer to the question of those who are being judged in Revelation 6:17 (cf. De Villiers 2004; Prigent 2001:278). The sixth seal proper comprises the scenario of judgment, which then leads on to the visions of the church as supplement and also as response to the climactic question in Revelation 6:17..$^{5}$

In this article, it will be argued that the author composes the sixth seal as a ring composition. ${ }^{6}$ This form of the sixth seal goes largely unnoticed in commentaries on Revelation (e.g. most recently, in Witherington 2003). Even Giblin (1991:90), otherwise a sharp analyst of the form of the text, fails to notice this compositional feature.

5 Prigent (2001:278) notes that the description of the wrath of God is so fearsome that it

provokes the questioning of those who confess Christ as their Savior: will his avenging wrath encompass all humanity? It is to this question that chapter 7 responds.

More attention is needed, however, for the fact that his question is asked by the inhabitants of the earth. The question that the believers ask is rather when they will be avenged through judgement on the inhabitants (cf. 6:10). And that question is the result of a common "perception that too long a period often intervenes between the commission of an outrage and its just recompense" (Aune 1998:424). The author and his followers are not really portrayed as uncertain and doubting. It seems to be part of the judgment of the inhabitants that they come to realize that they are without any hope in the presence of God the judge.

6 Lund (1992:372ff.) drew attention to what he considered to be the "chiastic" structure of the text. Because of the difficulties involved in writing about chiasms, his work did not receive the recognition it deserves. I am indebted to many of his insights in my own close reading of the text. For chiasm as a figure of speech, cf. Thomson (1995) and DiMarco (1979), but this important issue deserves a discussion of its own. 


\section{FORMAL ELEMENTS IN THE SIXTH SEAL}

Before attention is given to the sixth seal, some general remarks on form must be made. It is widely accepted that Biblical texts should be understood and interpreted in terms of their function in an oral culture (cf., e.g., Maier 2002:101-122). If this is the case, it can be expected that the formation of the material receives special attention. In his discussion of the oral nature of Revelation, Maier (2002: 107) wrote about the function of literary techniques like various parallelisms:

Repeating phrases or echoing/contrasting phrases in quick succession have an important function in solidifying what is heard in a listener's mind, as well as helping to promote a more vivid listening experience.

It is in line with this solidifying nature of John's text, that his language can be described as "aggregative rather than analytic" (Maier 2002:106). He adds:

This occurs first through the drawing out of nouns by placing them in identical or similar adjectival/participial phrases, or through the association of nouns and verbs with a discrete set of adjectives and adverbs. Or, second, aggregation occurs by placing clauses parallel to one another, or antithetically.

Such techniques enhance the oral communication of the text.

This explains why so many other literary techniques and devices are also found in Revelation. In an analysis of Revelation 7:4-8, Maier (2002:98), responding to a reading of this passage by Boring, draws attention to the "incantation-like recitation of numbers and names" in the description of the 144000 :

The Greek is musical. The repeated similar endings (bomoioteleuta) of phyles and chiliades offer a singsong assonance. Moreover, the repeated use of the perfect-passive participle esphragismenoi ("sealed") at the head of the list (v. $4 \mathrm{~b}$ ), then at the outset of the sequence (v. 5 ), and at its conclusion (v. 8c) offers a neat demarcation of a narrative episode through chiasmus and is an instance of paronomasia ... All this represents an aesthetic experience resistant to the analytical abstraction of Boring's translation.

The oral presentation of the text thus is not a simple matter of offloading information. Communicating with the text is much more 
than a rational process. The listener to the text becomes deeply involved in the reading process: $\mathrm{s} / \mathrm{h}$ e grasps "also experientially through being caught up in the readers' singsong recitation." The text "keeps the listener's interest and draws them into an emotional experience of the vision" (Maier 2002:99). One suspects that even if one did not know how to translate the words, the repetitious sounds would signal the importance of what is communicated. Meaning here resides as much in the sound-events as in the theological notion it expresses (Maier 2002:98).

Such remarks indicate that literary devices are not to be regarded as mere stylistic niceties. They can have important functions that significantly determine the communication process. This is equally true of the ring composition in Revelation 6:12-17, as will become clear below.

In the light of all this, the stage is set to analyze the sixth seal in terms of literary devices that determine its composition. This will be done first of all by a "visual" presentation of its structure. It is interesting how such a presentation on its own contributes towards a feeling for the effect of the text. The following arrangement gives such a representation of the manner in which the sixth seal is composed: 


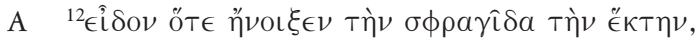

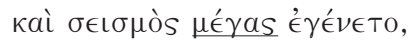

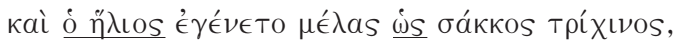

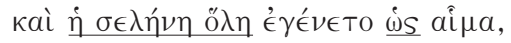

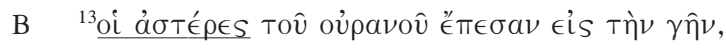

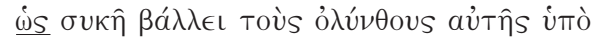

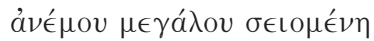

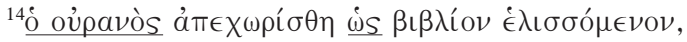
кaì $\pi \hat{a} \nu$ öpos

C

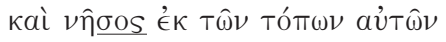

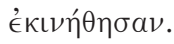

D

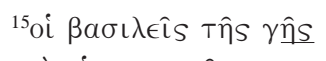
кaì oi $\mu \in \gamma ા \sigma \tau \hat{\alpha} \nu \underline{\underline{S}}$ kaì oi Xı $\lambda$ íapxou

E

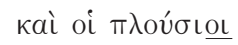
kaì oi ioxupoì

D

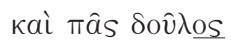

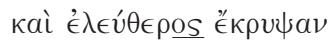

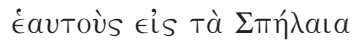

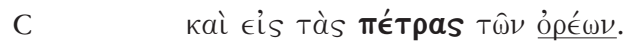

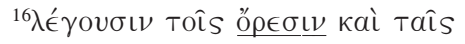
те́траıs,

$\Pi \epsilon^{\prime} \sigma \epsilon \tau \epsilon \in{ }^{\prime} \phi ' \dot{\eta} \mu \underline{\hat{\alpha} s}$

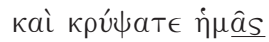

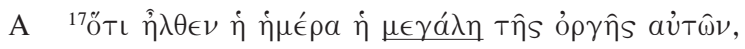

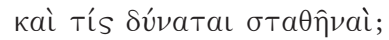

From this analysis the chiastic-like pattern is immediately obvious. A more detailed analysis will reveal other striking features of the text.

\subsection{The frame (A - A)}

It is, first of all, clear that the whole passage is framed by or forms a ring through the opening (6:12) and closing (6:17) remarks. The frame begins with the remark about the opening of the seal and the reference to a great earthquake (12). It ends with the remarks on the great 
day of wrath that has come and with the question about who is able to stand. On the face of it, the link seems to be tenuous if it depends only on the word pair ( $\mu \epsilon ́ \gamma a s / \mu \epsilon \gamma a ́ \lambda \eta)$. Their dissimilarity seems to be confirmed by the fact that the opening remark simply talks about an earthquake, whilst the closing remark refers to the great day of wrath.

Inter-textual references reveal the opposite. It is well-known that earthquakes are symbols for the coming or presence of God in judgment (Ac. 14:26; cf. Aune 1998:413). ${ }^{7}$ The great earthquake mentioned at the beginning is confirmed as indicating the arrival of the day of the great wrath of God and the Lamb at the end of the seal. The inhabitants of the earth are clearly terrified by the presence of

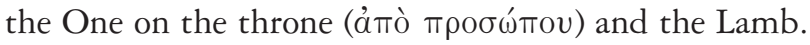

With this, the theme of judgment is formally wrapped around the contents of the first part of this seal as its frame (cf. further below). It is a seal in which the coming of the great day of the Lord is announced.

In Prigent's commentary (2001:276-277), the interpretation of this section appears somewhat fragmented exactly because the integration of the text through this frame goes unrecognized: he understands that the earthquake is "an entirely traditional apocalyptic theme" (referring to Mark 13:8, 24, 25). Later on, in Revelation 6:16-17, he comments about the Day of Yahweh that is being referred to. But he does not link the two explicitly.

When one uncovers the ring composition in this seal, the strong cohesion between the two elements that form the frame, comes to the fore and forces one to account for the link between them. The earthquake signifies the arrival of God in judgment. In a place where many earthquakes take place regularly (Aune 1998:424), this one is unique. It is not just another disturbance with serious consequences. It is the ultimate confrontation of God with evil.

7 Most commentaries refer to Joel 2:10, but see the fuller list in Aune (1998: 413). Aune (op cit) has an interesting discussion of the perception of earthquakes as prodigies. He notes, however, that "earthquakes are often expected to occur in the end time as one effect of the presence of coming of God" without relating this to Rev. 6:17. The ring composition in this seal favours a primary link with the earthquake-motif in Hebrew Scriptures. 
It is telling how sound operates in this frame and solidifies cohesion: note the intense repetition of the Greek $\eta$ in 6:17a, as well as the $\alpha$ - an al-sounds in the closing phrase in $6: 17 \mathrm{~b}$. This need to be compared with the formulaic beginning of $6: 12 \mathrm{a}$ and the $\sigma$-sound in $6: 12 \mathrm{~b}$. In the last case the reason for the variation $\mu \epsilon \cos / \mu \epsilon \gamma a$ a $\lambda \eta$ has become clear. The author uses a word that brings out the assonance.

\subsection{The inhabitants of the earth (D - D)}

The composition of this seal is easier to follow if one works from the middle part (Rev. 6:15) outwards.

The list as a whole forms a unit in so far as it refers to human beings (in contrast to the heavenly and cosmic phenomena in the previous part) and narrates their fearful response to the dark events that are happening around them. Prigent (2001:277) correctly notes that they "have quite evidently been chosen in order to encompass all of human society." This is why they are grouped together by the reference in the first phrase to "the earth" (oi $\beta a \sigma l \lambda \in \hat{\imath} s$ Iñs $\gamma \hat{\eta} s$ ). The very significant phrase, $\tau \hat{\eta} S \gamma \hat{\eta} s$, is full of meaning. It recalls the

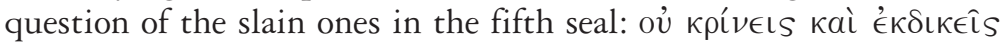

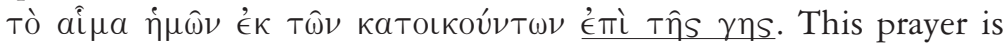
addressed to God from under the altar which is "always situated in heaven" (Giblin 1991:86), so that it represents a heavenly perspective on earthly events. In line with this is that

\footnotetext{
throughout the body of Revelation, prayers are always voiced or depicted on the heavenly plane - within the ambit of God's throne - and are correlated with the subsequent course of events upon the earth (Giblin 1991:86).
}

The earth thus takes on a negative meaning as site of opposition to God. The saints are in heaven because of their having been slaughtered on earth in the first four seals. This is confirmed by the insight of Eller that "kings of the earth" is a theological category and denotes the enemies of God par excellence (cf. Prigent 2001:277, note 1). Revelation 16:14-16 and 17:2, 18 will confirm the importance of kings as enemies of God, but will also stress the link between them and the whole world. The references to the kings and the other inhabitants of the earth make up a list of the depraved opponents of God. 
It is headed by the kings of the earth, but followed by others who rejected God (cf. also Maier 2002:149). It is, therefore, clear that the groups mentioned in the middle of the sixth seal find coherence in the fact that they inhabit the earth as place of evil.

But there is a more important indication of coherence. The number (7) of the groups is striking and is mentioned often in commentaries (e.g., Prigent 2001:277; Giblin 1991:90). The place and pattern in this group of seven are, however, not always discussed. A close reading yields the following significant insights:

First of all, the list appears in the middle of the sixth seal and as such draws attention to itself.

Secondly a pattern of $2+3+2$ is developed: "Kings and magnates" that form a first pair and "slaves and free" as the second pair, frame a middle group that consists of three: the generals, the rich and the powerful. The author uses sound as a subtle compositional technique to structure his material in this way: The triplet in the middle is formed by the repetition of the ending -ot, reinforced by the repeated кai oi before each of the three:

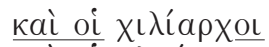

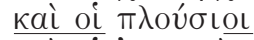

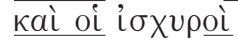

The couplets on each side of this middle are both also grouped by

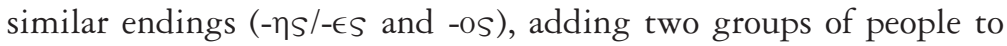
the middle group and framing them carefully. Both belong together semantically as well: in the first case they denote those in highest authority, whilst the second pair antithetically links the freedmen and slaves (for the latter, cf. also Rev. 13:18; 19:18 where they are also firmly linked). But both pairs are also semantically linked in so far as they represent the important of society (kings and magnates), but also those on the lower levels (slave and freed slaves).

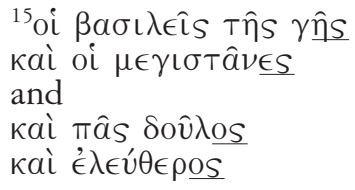

These sound patterns in the two outer frames of the middle tripartite group, thus confirm the $2+3+2$ pattern beyond doubt. 
The unique pattern is further confirmed and explained by other lists in the book in which such groups reappear. In Revelation 13:18, for example, the activity of the second beast is described:

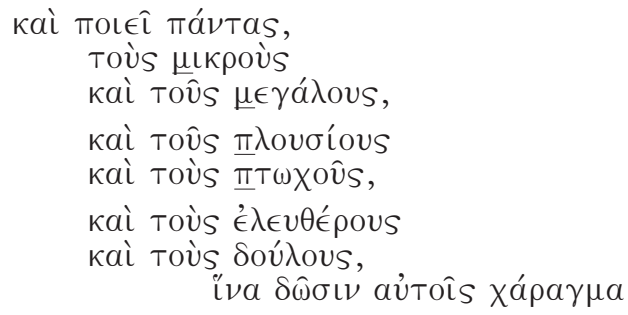

These six references, to some extent similar to the list in Revelation 6:15 (cf. Aune 1998:419), are grouped in three. All three are semantically related in an antithetical manner. But what is striking here, is that the first two groups are also linked through the $\mu$ - and $\pi$-sounds. The same principle is therefore also at work in this list, but applied in a different manner (not as a ring composition, but as three antithetical parallelisms).

\subsubsection{The rich $(\mathrm{E})$}

There is, however, a further formal ordering of this threefold unit. The middle triplet is clearly in focus. The three groups are prominent enemies of God, as is clear from the list in Revelation 19:17 of those who have been conquered by the Rider on the white horse. They are also listed in the first place there.

In the middle of this middle stand the rich. They are framed by two phrases in which the $\chi \mathrm{l} / \chi \mathrm{v}$-sound is prominent. These two phrases (oi

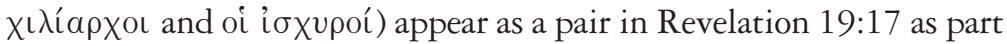
of a list of conquered enemies of the Rider on the white horse. It is striking that they are separated here in Revelation 6:15 by the reference to the rich. The rich thus draw attention and has a prominent position.

Also insightful is the fact that in Revelation 13, quoted above, the rich are mentioned together and contrasted with the poor. There is no mention of the poor in the sixth seal. The omission means that the insertion of the rich is even more conspicuous.

The rich, together with the generals and the powerful, form a mighty group, placed in the middle of the seal. They are the faces and instru- 
ments of the violent (military) and economical forces of evil that attack the church. In the light of the economic critique that is so prominent in the book it comes as no surprise that they are mentioned here in an equally telling manner. A significant confirmation of the author's feelings about wealth can be found in Revelation 21:24 and $26^{8}$ where it is said that the kings of the earth and the people will bring their glory into the New Jerusalem. In this place the proper function of wealth is indicated - it should be used to glorify God.

In general, then, this middle part shows how the author patterns the different groups into a unit by employing literary devices like homoioteleuta, assonance, parallelism and antithesis.

\subsection{Cosmic phenomena (C - C)}

Equally striking is the way in which this middle part with its groups of people is in turn framed by cosmic phrases - mountain and island at the beginning (6:14) and rocks of mountains and mountains on the other side (6:15-16). The word ópos is (like $\mu \epsilon ́ \gamma a s / \mu \epsilon \gamma a ́ \lambda \eta$ in the frame) repeated conspicuously. There are also similar sounds and endings:

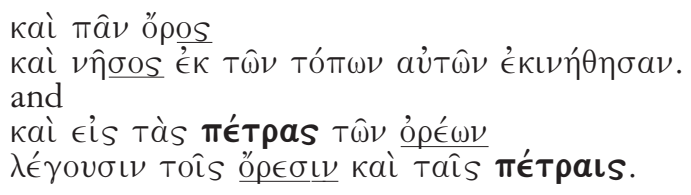

The last two phrases in $15 \mathrm{~b}$ and 16 create a true chiasm, indicating how intensely the author is busy structuring his material on even the lowest level.

\subsection{Heavenly phenomena (B - B)}

It is on this level that the pattern is most obscure. The two elements $(6: 12 b-14 ; 6: 16 b)$ on their own are nicely formed.

8 Aune (1998:1173). Actually the phrase "glory and honour" probably has a double meaning and includes wealthy gifts as well as fame and adoration. Cf. below where attention will be drawn to the danger of wealth as spelled out in the letter to Laodicea and to the function of the motif of wealth in the sixth seal. 


\subsubsection{The first element}

The following pattern in the first element catches the eye, once again not only because the heavenly bodies are semantically linked, but also because of the formal link, by the position of the sun, moon, stars and heaven in the sentence initial place, but especially through the is phrase: ${ }^{9}$

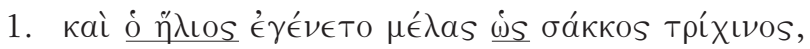

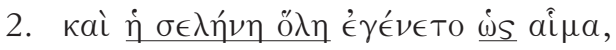

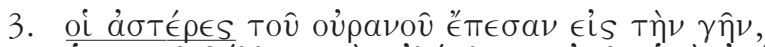

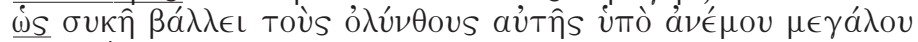

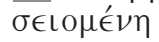

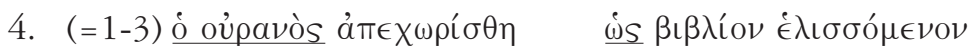

What is remarkable here, is the longer $\dot{\omega}$ s phrase in the third element, the stars. It only makes sense if one takes into consideration that the first three elements, sun, moon and stars are heavenly bodies and located in heaven. The fourth element thus encompasses the first three. That is why the author formally distinguishes the first three from what follows in the longer fourth phrase in which heaven is mentioned. By grouping the first three (sun, moon and stars), he succeeds in letting the focus fall on heaven, mentioning it in the last place.

It is only when one considers the contents of this last phrase that the reason for the emphasis becomes apparent: there is a clear ironical twist to these events brought about by the earthquake. The heavenly bodies are dramatically affected, but more so, heaven itself was rolled up like a folded scroll ${ }^{10}$ during the process that the penultimate seal of the folded scroll (Rev. 5) was being opened. The unfolding of God's plan brings about the folding up of the old structures like heaven and its constitutive parts. Extraordinary cosmic and heavenly events will take place when the end is near. This first element shares motifs that are heavily apocalyptic in tone and that are taken over from various prophecies about the Day of the Lord.

9 Aune (1998:414) notes this pattern and draws attention to the aorist-form in which the declarative statement is made.

10 Heaven, as Aune (1998:415) translated the Greek phrase, "disappeared from sight." 
In view of this widespread association, it is obvious that the author of Revelation intends the readers to think that the Day of the Lord is ushered in with the sixth trumpet (Aune 1998:414).

\subsubsection{The second element}

The second element (B1) is also nicely balanced in 16 through similar sounds, word positions and phrases:

$\Pi \epsilon^{\prime} \sigma \in T \epsilon \dot{\epsilon}^{\prime} \dot{\eta} \mu \hat{\alpha} \underline{s}$

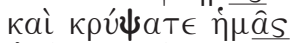

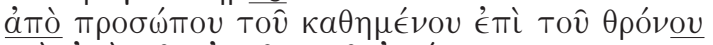

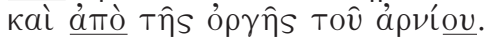

The two elements thus both have a fourfold pattern.

\subsubsection{The relationship between the two elements}

The serious problem is whether and how they $(\mathrm{B} / \mathrm{B} 1)$ relate to each other: the first element (B) refers to the different heavenly bodies, whilst the second element apparently lacks any link with it. The relationship between them is therefore not immediately clear.

Fekkes (1994:161), however, made an interesting suggestion that illuminates their relationship in terms of their contents. According to him, John alluded to Isaiah 34:4 in his description of the heavenly

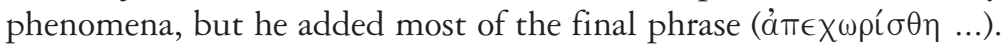
In doing so, an important new development takes place. John wrote about much more than merely another cosmic sign:

Rolling up the heaven would completely remove the barrier between God's throne and the earth, and usher in the eschatological confrontation between God, the Lamb and the sinful world. ${ }^{11}$

The disappearance of heaven meant that there was no longer any barrier between God and humanity. This, then, would provide the link with the second element. That element contains the expression ámò проби́тाо referring to the terrifying presence of God and the Lamb.

11 This reading is present in the mind of the author, as is indeed proven later on in Revelation 20:11 where it is said that the earth and heaven retreat before the One on the throne and all the dead appear before God's throne. According to this verse, and reminiscent of the expression in Revelation 6:14 where it is said that mountains and islands are moved from their places, there is no longer "place" for them. 
Taken together, they indicate that this presence is the direct result of the heavenly events and the receding of heaven described in the first part of the sixth visible manifestation (Fekkes 1994:161) of God and the Lamb. That is why they try to hide. ${ }^{12}$

The analysis of Fekkes, based on contents and on links with Isaianic traditions, is confirmed by the formal analysis that shows how the heavenly events frame the cosmic events. The flow of the ring composition brings these two elements together in a formal manner.

The overall effect of this link is to interpret the extraordinary events as an indication of the wrath of God and the Lamb as it will become evident in the last battle before the end. Fekkes (1994:166) notes that the signs described in the sixth seal have to do with the eschatological battle. This section with its holy war theme relates to the final battle led by the Rider on the white horse in Revelation 19:1-11. After that final war, heaven and earth will be removed and not only affected as in this sixth seal. This could also explain the middle section of the list of inhabitants that refers to the generals and powerful. They represent the military and violent institutions.

This is then further confirmed by the outer frame of the sixth seal (A - A). The effect of the seal is intensified through the outer frame: the sixth seal, with its earthquake is about the great day of wrath before which no one can stand - especially those who were so powerful, but who were clearly not as powerful as they thought.

\section{THE SIXTH SEAL WITHIN ITS CONTEXT}

The sixth seal ends with a question about who can stand in the light of the Day of Judgment. The answer is given indirectly in the seal: heaven, the world, and its inhabitants cannot stand before this revelation of the wrath of God.

This question of the unbelieving inhabitants of the world fits the sixth seal into its immediate context, since it recalls the question of

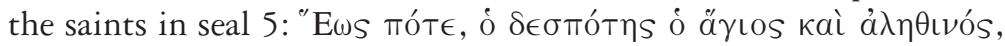

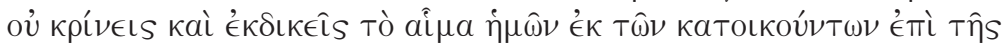

12 Revelation 21:1-3 will indicate how this is different for the faithful who will experience God's immediate presence as consolation. 
$\gamma \hat{\eta} s$. Both these questions appear in prominent positions. In the fifth seal, the question is put in its middle, whilst the question in the sixth seal appears at the end where it forms part of the frame that "rings" the sixth seal and requires that it should be understood from that perspective.

The fact that they are placed in such prominent positions in two seals that follow each other, will obviously force the listener to compare them. This will happen even more because both of them have to do with the inhabitants of the earth. The saints formulate their

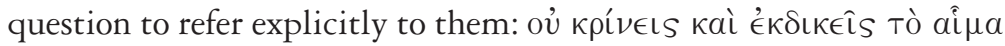

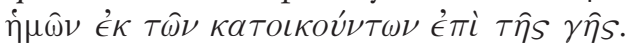

The question of the saints is partially answered in the sixth seal: the great day of the Lord, the great day of his wrath will bring all the inhabitants of the world to cry out in despair when they experience everything as shaking. Those who have killed the saints and spilled their blood (6:11) will hide in the caves and among rocks. They will call out to the earth to hide them from the One on the throne and the wrath of the Lamb (6:16). But the earth itself will be shaken by the wrath of the One on the throne and the Lamb. They will not be able to escape the judgment.

In seals 5 and 7 the mirror image of seal 6 is revealed. The saints, who are now under the altar, in the presence of God for whom they had sacrificed their lives, ask God a question to which they are given an answer. This question can be described as a prayer. In seal 7 an angel with a golden censer mixes their prayers with incense and offers them to God (8:4).

This contrasts starkly with the actions of the inhabitants of the earth. When they are confronted with the presence of God, they hide and call on, or "pray" to the earth, to the mountains and rocks, to keep them from the wrath of God (6:16). The listeners know that their call to be "saved" will go unheeded, since the earth is itself being moved on judgment day. In fact, at the end of seal 7 the angel throws a censer with fire on the earth in a final act of judgment. A cacophony of sound, lightning and earthquake follows (8:5), indicating the last moments when the lights shall go out and the anguished cries of the oppressors will be heard no more. 


\section{THE CONTENTS OF THE SIXTH SEAL}

The sixth seal reflects a remarkable structure. It was carefully composed as a ring composition. Its constitutive elements are carefully balanced. It focuses on the day of wrath (outer frame) when God will appear in judgment (middle frame) on the inhabitants of the earth (centre). At its beginning the focus is on the events themselves: dramatically the earthquake is mentioned. When the seal continues to narrate terrifying signs that happen to the heavenly bodies, the listeners are helped to realize that this is not the "normal" earthquakes that occurred often in Asia Minor. This one culminates in the disappearance of heaven. But then the world is also affected when cosmic events follow on the heavenly ones: the land and sea, normally the places where people find a firm footing, are moved out of their places. Nothing of the past certainties is secure any more.

With this the scenario is set for what follows: the effect of the heavenly and cosmic events on the inhabitants of the earth is related. In the heart of the seal the inhabitants of the earth, including especially those who have always been so powerful and secure, are all portrayed as terrified. But more than this happens: they themselves practically interpret these events by what they say in a theological sense. They hide themselves in the caves and rocks of the mountains. They understand, but they do not repent. And then, secondly, they address the mountains and the rocks and ask them to hide them. Although they had experienced that the mountains, regarded as the firm and safe places on earth, were moved out of their places, they still try to find protection from them in what is clearly an act of desperation. They hide themselves and they request to be hidden further. They then indicate that they truly understand the message of the heavenly and cosmic events when they motivate their request by referring to the presence of the One who sits on the throne and the wrath of the Lamb. Since the heaven disappeared, they stand before God and the Lamb and are in full vision of the throne (Rev. 4-5). They finally also indicate that they comprehend the finality of these events when they describe them as signs of the great day of the wrath of God and the Lamb that has arrived. Terrified, they then ask the mountains and the rocks who will be able to withstand. 
The elements of the ring composition interpret each other mutually, as is to be expected in such a construction. But it is significant that there is at the same time clear progression: what is a great earthquake $(\mathrm{A})$ is interpreted at the end as the great day of the wrath of God and the Lamb (A). The heavenly events and the disappearance of heaven (B) allow the inhabitants of the earth to see God and the Lamb (B). The cosmic events (C) indicate the fallacy of trusting the earth and disobeying God (C). The inhabitants include the few powerful (D) and the normal (D), but especially those who wage war in a military and economic (Rev. 13:16-17) sense.

This intensification within the seal also takes place in terms of its relationship with similar descriptions later on. It announces and describes this event sparingly, preparing and allowing for its more extensive portrayal in later parts (e.g., Rev. 8:5, 16:17-21 ${ }^{13}$ and 19:1-11). ${ }^{14}$ It is, nevertheless, an intense presentation — providing a fitting response to the question of the faithful who suffered so much under the inhabitants of the earth and their evil instigators. In this seal, then, a spiral development takes place - just as in the macro-text as a whole.

\section{THE FUNCTION OF THE SIXTH SEAL}

These comments open interesting new possibilities for understanding the text of Revelation. As this may not be so evident, some further remarks on the function of the sixth seal need to be made. This will be done in terms of the names of groups in the middle part of the seal.

The list of the inhabitants does not always elicit enthusiastic reading. Aune (1998:419) represents the normal perspective of researchers on this long list with his laconic observation that the verse "is a complex way of saying "everyone." Prigent (2001:277), in similar line and equally brief, also stresses the comprehensiveness: "The list comprises seven items which have quite evidently been chosen in order to encompass all of human society."

13 In Revelation 16:17-21, for example, the intensification and progress in narration is clear when it is said that all of the islands fled away and the mountains were no longer to be found.

14 This would be an indication of the spiral movement of the narrative. 
But why then does the author say a simple thing in such a cumbersome manner? Why then the presentation of the information with techniques that are so intricately linked to sound, as was portrayed above? How does sound contribute to the function of the text? In what way would it stimulate imagination and involve listeners in the process of communication?

One can only find an answer if one imagines the response of an audience who heard this list being read. Such a response can be reconstructed by intra-textual references. As they listened to the sixth seal, the listeners had images from the seven letters fresh in memory. They had heard the description of their situation in the letters to the two faithful churches of the poor, oppressed Smyrna (Rev. 2:8-11) and the faithful, frail Philadelphia (Rev. 3:7-13). They remembered, for example, how both would be protected by God in the difficult times and that both would receive a crown if they stay committed in their witness. The strong that tested the little power of Philadelphia so thoroughly, the oppressors that persecuted the Smyrnean believers, the faithful listeners hear in the sixth seal, were now on the run, desperately crying out to the elements that they thought they controlled so well, to protect them from God. They also remembered the warning against the Laodiceans who celebrated their wealth without realizing how poor they were. From the intense remarks about the arrogance of the rich Laodiceans, they realized that wealth can be dangerous.

To them, within this context, this list with all its constitutive elements would signify the fulfilment of the pronouncements and promises given at the beginning of the book. The list therefore created coherence with the rest of the book, providing more information about what was said earlier on.

The author of Revelation, as Barr (1998) indicated convincingly in his narrative analysis, composed his work in such a way as to guide his listeners, but also the reader, in the process of performing the book. He even suggests that the reader of the book had to prepare well for the performance, as is evident from Revelation 1:3, where, in the first of seven macarisms, he referred explicitly to the reading and its salvific consequences. Here the author combined the experience of salvation with reading of, and listening to, the book (Rev. 1:3). 
If the author were so careful about the presentation of his book, it is to be assumed that he would want his book to be understood well. The analysis of the sixth seal given above, confirms this. A ring composition is ideally suited for guiding proper understanding: in a first line of development there is a listing of statements (ABCD) that provides basic information. Then follows an interpretation of these elements in reverse order in which they are explained further, underlined and clarified in a second line of development (DCBA).

Except for this literary function and the rational effect that such informative links may have, the list functions on an existential level as well. In their intense situation, characterized by feelings of persecution, they faced the real possibility of paying the highest price for their faith. The fear for their persecutors could determine their response and their lifestyle, paralyzing them or bringing them to compromise. The text addresses these fears. Listening to and participating in the reading, they became aware of the deeper reality of God's visitation of evil that was proclaimed and promised over so many centuries to believers of all times. They were further aware of the Christian proclamation that confirmed God's end time judgment on evil. Now, as still more confirmation, the prophet John brought his message to strengthen their faith and to make them face evil fearlessly.

The audience was given the existential information and interpretation with sonorous, rhythmic sounds and language that promoted the process of understanding and involvement even more. The text was given a poetic quality, promoting the esthetic experience that stimulated the existential involvement further.

\section{THE LITURGICAL FUNCTION OF THE SIXTH SEAL}

But this is only a partial answer to the question about the reason for this special composition. Another possible and more revealing reason may be found in the way in which the book of Revelation is related to liturgy. This link intensifies the appeal and effect of the book.

First of all, some general comments about this link have to be made. The liturgical character of the book has received some attention in modern research. Perhaps the most remarkable, but mostly unno- 
ticed, remark about this is to be found in the famous commentary of Charles. He concludes his introduction (1920:ix-xx) to his work with two remarks on its nature and its contemporary relevance. Though Revelation is an apocalyptic text about the dark conflict between God and evil, he writes, it is in the first place a book full of hymns (1920:xiv: "His book is emphatically a Book of Songs"). For Charles these hymns are of fundamental importance to understand the character of the book. There are lamentations and threnodies - but not about those who are sacrificing their lives because of their faith. The lamentations come from the sinners in the face of the approaching judgment. The hymns of the martyrs, on the other hand, are praise songs, directed to God. "Blessed are the dead who from now on die in the Lord," says the second macarism in this book (Rev. 14:13). Inexhaustible faith and a triumphant joy are expressed in hymns of praise, joy and thankfulness.

These insights were given explicit attention when, in the early fifties of the previous century, Cullmann (1953:7) began his influential book on early Christian worship and the sacraments, with the remark that except for certain parts in Acts 2 and 1 Corinthians, Revelation is one of the major sources for the study of early Christian worship. He writes,

[A] further important mine of information is the Book of Revelation of St. John, for it is not without significance that the Seer mentions that he saw his visions on a "Lord's Day" (1.10), at a time, therefore, when the Christian community was gathered together. Thus he sees the whole drama of the last days in the context of the early Christian service of worship which, so to speak, has its counterpart and at the same time its fulfillment in the coming aeoon, so that all that takes place in the gatherings of the early Christian community, appears as an anticipation of that which in the last day takes place from God's side. Hence the whole book of Revelation from the greeting of grace and peace in chapter 1.4 to the closing prayer: Come Lord Jesus, in chapter 22.20, and the benediction in the last verse, is full of allusions to the liturgical usages of the early community (secondary italics).

Other parts of the book confirm this. Revelation 1:3 evokes the worship service as the most fitting context for the process of reading 
and listening to the book. ${ }^{15}$ The presentation of the prophecy as a letter and the conclusion $(1: 3 ; 22: 21)$ reveal the author's wish to have it read in the worship service. In the same line, Revelation 1:6 and 7 concludes with the telling Amen-call. The climactic denouement of the worship service was the Maranatha prayer (22:20) that the spiritual presence of Christ should be replaced with that time in which every eye will see and worship Him.

Having made these observations, Cullmann (1953:25) then adds,

In general the liturgy in the first congregations is something extraordinarily alive, and liturgical formulae show no sign of being paralyzed. All members take part in the liturgy.

With these insights, Cullmann prepared the way for a more sophisticated understanding of the function of the book. The material in it has to be understood in terms of the self-understanding of early Christianity within the context of liturgy and worship.

The French scholar Prigent developed these insights more fully. ${ }^{16}$ He (1964:79) argued that the allusions to the worship setting indicate that the early Christian cult had more then mere educational qualities. Through liturgy believers actually participate in and experience the end. The gates of paradise are opened and they enter the heavenly, eternal Jerusalem. ${ }^{17}$ Recently Prigent (2001:276) wrote that

15 Aune (1998:11) remarks that the kind of pronouncement in Revelation 1:3 were used in early Christianity to introduce or conclude readings. He calls Rev. 1:3 and 22:7 "liturgical formulae."

16 Prigent (1964:7) defined liturgy in a wide sense when he wrote:

Nous appellerons donc éléments liturgiques tout ce qui, de près ou de loin, est susceptible d'être compris comme allusion à la vie culturelle de l'Eglise: images, mots, doctrines et pratiques. Naturellement on pensera d'abord à tout ce qui se rattache aux sacrements, mais il faudra bien prendre garde de ne pas négliger un autre aspect possible de la vie liturgique de l'Eglise primitive: le culte, qu'il soit ordinaire ou plus solennellement consacré à telle occasion particulière (secondary italics).

17 In that same period, Caird (1966:301) concluded his commentary on Revelation with the remark that the book opens and ends with liturgy. He also refers to the reference to John's being in the Spirit on the Day of the Lord (Rev. 1:10) and the Maranatha prayer at the end that assumes the Eucharist. To him, this is 
the question of the saints in Revelation 6:10 (how long it will take before their blood is avenged), should also be understood in a liturgical setting. He notes that the worship service is the place where people proclaim that

they intend to worship God alone, to obey him, and to receive everything from him. This is the anticipation of the End. The faithful, among whom must be ranked in first place the confessors and the martyrs, make present in a significant way the victory of Christ; they are the living token of the reality of the new world as well as of judgment.

As such the worship service plays the role of accelerating the End. According to Prigent, then, there is a

very close and profound relationship between worship and apocalyptic: what is revealed in the apocalypses to privileged seers, is communicated to the faithful in liturgy: namely that the faraway heaven and the awaited future are fully present before God as now, and that the Lord offers to those who worship him the possibility of discovering here and now the reality of this revelation (1998:32).

Also with these insights, material in the book appears in a new light.

Vanni (1991:348ff.) showed how important such a liturgical context can be for an understanding of the narrative flow of Revelation, when he proved that the seemingly incoherent Revelation 1:4-8 is in fact a carefully structured antiphonic hymn in which reader and listeners are engaged (cf. also Aune 1998:28). The form of the narrative and the literary devices are seen in a new light when the book is framed by liturgy. With Vanni's work, for example, the striking double liturgical use of "amen", noted by Cullmann, is understood even better. But even more so, it is now clear how the author composed his work in this small section at the beginning of the book in terms of antithetical parallelism (reader — audience).

the frame for understanding the eschatology of the book. Taking up a position that reminds one of Prigent's comments, he notes:

He and his fellow Christians had no difficulty in believing that the end could come to meet them in the midst of time. For week by week their prayer Maranatha, Come, Lord Jesus, was answered as they kept their tryst with him who was Alpha and Omega, the beginning and end. 
In this way it is understood that the author designed his work with its oral presentation within a liturgical setting in mind. He wanted the audience to participate actively and experience his message in its liberating and empowering impact within their regular religious meetings. ${ }^{18}$

These liturgical studies pave the way for similar work to be done in terms of the rest of the book. Here certain possibilities relevant to an understanding of the liturgical function of the sixth seal can be mentioned only briefly. The sixth seal culminates in a lamentation by the inhabitants of the earth - reminding one of the observations of Charles about the evil ones who reveal their fears about their fate in hymns. One can imagine the Christian audience listening to the recital of its contents, following the disastrous events that overcome their powerful opponents and now, at the end, experiencing their lamentations. They are actively drawn into the events by what is being said so eloquently about their opponents. They experience God's future judgment that is "fully present before God as of now" (Prigent 2001:32).

Intra-textual references abound with which the experience of the readers can be developed. They hear how their opponents and the instruments of evil forces pray to the mountains and the rocks in songs of lamentation. And to them it is a reinforcement of God's rule and its victory over the forces of evil. In this, they are on the side of the slaughtered saints who pray for God's righteous judgment (Rev.

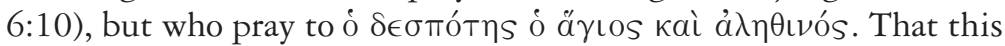
question can be placed in a liturgical context, has been suggested by Prigent (cf. above).

One could also pursue such suggestions as those of Barr (cf. above) that the author composed his work carefully to make sure that the readers experience it in this way. Wanting them to hear this description in a worship service, he uses literary devices in order to promote liturgical conventions and dynamics. The impact of the text is greater when it is understood that reader and audience are located in a litur-

18 For other research with implications for the liturgical nature of Revelation, cf. Newson (1985) who edited the Songs of Sabbath Sacrifice, a Qumran text, and argued that it displays surprising similarities with Revelation (for an appraisal, cf. Prigent 2001:22ff.). 
gical context. In the holy space where they anticipate God's eschatological victory, the text plays a major role in confirming exactly that; not only in terms of contents, but also in the way in which it is composed, read and imaginatively appropriated. As they listen to the reading, it becomes part of their religious experience and sinks into the fibre of their being. As such it promotes consolation and stimulates perseverance. This would explain the use of sound in the text of the sixth seal. It is well-known how and what sounds are effective in contemporary worship service that involve listeners emotionally and affect their behaviour. The role of sound thus not only serves to pattern the narrative and create cohesion between narratival elements, but it enhances the esthetical experience and ultimately also the liturgical involvement of the audience.

\section{CONCLUSION}

Prigent (2001:21), having offered an overview of the recent history of the exegesis of Revelation as an introduction to his commentary, noted the progress that can be detected in the field as a result of this work. He then continues with most interesting remarks: Progress is not "the heart of the matter." More important is

an awareness, which is often muffled but is always ready to reappear, that whatever approach we may take to the text, we must always bear in mind that it remains instrumental and therefore approximate and necessarily inadequate (secondary italics).

One needs to restate the truism that no exegesis "could ever claim to have assimilated the text." With these rather common sense remarks he underlines that exegesis, and especially methods of exegesis are attempts by later readers to decode the meaning of the text. They are therefore subordinate to the text and clearly relative to those who try to decode the text.

Prigent then continues with a "second, more marked reflection that will undoubtedly appear less obvious to certain readers." In past times, he notes, certain "ground swells" overwhelmed the history of biblical exegesis. They have "drowned the text and retained only their readings of it." He admonishes that it is important for exegesis to remember that its task is not to preserve a method. It should rather 
be sensitive to the fact that the text as it has been generated at a given point in time is the object of research.

This is best illustrated by a footnote of Prigent (2001:22, n. 60) which reflects the temporality and relativity of scholarly research. In it he refers to recent work by three scholars (Giesen, Vanni and Bauckham) that has

set aside these debates (as explained by him) with a sweep of the hand, or have preferred to ignore them in order to pursue without hesitation their work as exegetes.

Although it could be argued that his characterization of some of these scholars may be too one-sided, (Bauckham, for example, in some ways engages intensely with and continues traditional scholarship), there is much validity in his observation. The study of Revelation as a carefully designed text by these scholars certainly represents a decisive step away from what was at the heart of the traditional form critical and genetic approaches to the book which were so prevalent only generation ago. Their scholarship is indeed an illustration that research can sometimes deviate dramatically (even cruelly) from the beaten track. ${ }^{19}$

The New Testament has a textual nature focusing on the text as its object. Because it is at the same time a theological field, the focus on the text can be motivated in a theological manner.

To ignore this (the text as historical fixation at a given point of time) is to refuse to recognize Scripture as the only incarnation that can testify to the Incarnation. ${ }^{20}$

19 One is amazed that, in his commentary on Revelation, Malina (2000:12) can write:

There are no clear, unambiguous, or direct references in the work to Rome or to Roman emperors. While this is the favorite historical reference for most modern scholars, there is really no proof for this tenuous hypothesis aside from gratuitous insistence (for example, see Aune 1998:2:829-31).

Whether this remark is justified or not, is another matter. The point is how volumes and decades of research can be discarded with such a remark in favour of a very different (astrological) approach to the text.

20 The remarks of Prigent are so important because they contradict the misunderstanding that a close reading of a text and respect for its integrity represent anachronistic and ahistorical approaches. His discussion of the problems of tra- 
This intensifies that responsibility of the exegete to respect the integrity of the text.

It is in this context that the close reading presented in this article should be understood: it offers a close reading of the text in terms of its composition that makes a decisive difference to the understanding of the book. The special rhetorical nature of the sixth seal with its ring composition was then fitted in a liturgical context and the function spelled out. When we work through Revelation as text in this way, wrestling amongst others to comprehend historically the minute details of its compositional nature, we discover the limitations of earlier interpretive work and the need for new, creative solutions to its meaning. We then recognize how the text survives generation after generation of scholars who apply method after method to decode meaning. As we understand this, we accept that methods are tentative, temporal, in need of constant revision or replacement. And this in turn makes us aware of how important our discipline is. Its outcomes can be vital for the life of individuals and communities.

As we celebrate the long existence of institutions of learning in which we work, it makes sense to reflect on our own theological research in order to enhance its integrity and reputation. Within their context we are generating knowledge that builds on the past and that decodes new understandings for the present for the well-being of church and society. It is a never ending story that takes us on a fascinating journey.

ditional historical critical readings of Revelation "until the 1970's" (Prigent 2001:3) and the positive contribution of recent studies is valuable especially because he stresses so articulately that this represents a historical enterprise. 


\section{BIBLIOGRAPHY}

Aune D E

1998. Revelation 6-16. Waco: Word.

BACHMANN M

1986. Der erste apokalyptische Reiter und die Anlage des letzten Buches der Bibel. Biblica 67:240-75.

1998. Noch ein Blick auf den ersten apokalyptischen Reiter (von Apk 6.1-2). NTS 44:256-78.

\section{BARR D L}

1998. Tales of the end: a narrative commentary on the Book of Revelation. Santa Rose: Polebridge.

\section{BAUCKHAM R J}

1993. The climax of prophecy. Studies on the Book of Revelation. Edinburgh: T \& T Clark.

1993. The theology of the Book of Revelation. Cambridge: University Press.

\section{BEALE G K}

1999. The Book of Revelation. A commentary on the Greek text. Grand Rapids: Eerdmans.

\section{BORNKAMM G}

1937. Die Komposition der apokalyptischen Visionen in der Offenbarung Johannis. ZNW 36.

\section{CAIRD G B}

1966. The Revelation of St. John the Divine. Edinburgh: T \& T Clark.

\section{Chevalier J M}

1997. A postmodern Revelation. Signs of astrology and the Apocalypse. Toronto: University of Toronto Press.

\section{Collins A Y}

1984. Crisis and catharsis. The power of the Apocalypse. Philadelphia: Westminster.

\section{Cullmann O}

1953. Early Christian worship. London: SCM. Studies in Biblical Theology.

\section{DE VILLIERS P G R}

1999. Obscure symbols in the Book of Revelation in the light of Graeco-Roman Pagan oracles and prophecies. Acta Patristica et Byzantina 10:66-88.

2002. Renaissance and religion. Acta Theologica 22:19-46.

2004. The role of composition in the interpretation of the rider on the white horse and the seven seals in Revelation. HTS 60:125-153.

\section{DiMarco A}

1979. Der Chiasmus in der Bibel 4. Linguistica Biblica 44:3-70. 


\section{FeKKes J}

1994. Isaiah and prophetic traditions in the Book of Revelation. Visionary antecedents and their development. Sheffield: JSOT. JSNTSSS 93.

\section{GiBLIN C H}

1991 The Book of Revelation. The open book of prophecy. Collegeville: Liturgical. Good News Studies 34.

\section{HARRINGTON W J}

1993. Revelation. Collegeville: Liturgical. Sacra Pagina 16.

ISRAEL J 2001. Radical enlightenment. Philosophy and the making of modernity 1650-1750. Oxford: Oxford University Press.

\section{KerkesLager A}

1993. Apollo, Greco-Roman prophecy, and the rider on the white horse in Rev. 6.2. JBL 112:116-21.

\section{KNIGHT J}

1999. Revelation. Sheffield: Sheffield Academic Press. Readings. A New Biblical Commentary.

\section{KRAFT H}

1974. Die Offenbarung des Johannes. Tübingen: Mohr.

\section{LAMBRECHT J}

1998. The opening of the seals (Rev 6,1-8,6). Biblica 79:198-220.

\section{LOHMEYER E}

1953. Die Offenbarung des Johannes. Tübingen: Mohr. HNT 16.

\section{LUND N W}

1992. Chiasmus in the New Testament. A study in the form and function of chiastic structures. Peabody: Hendrickson.

\section{Malina B J \& PilCh J J} 2000. Social-Science commentary on the Book of Revelation. Minneapolis: Fortress.

\section{MAIER H O}

2002. Apocalypse recalled. The Book of Revelation after Christendom. Minneapolis: Fortress.

\section{MOUNCE R H}

1977. The Book of Revelation. Grand Rapids: Eerdmans. NICC.

\section{Newsom C E}

1985. Songs of the Sabbath sacrifices: a critical edition. Atlanta: SBL.

\section{PRIGENT P}

1964. Apocalypse et liturgie. Neuchatel: Delachaux et Niestlé. Cahiers Théologiques 52. 
2001. Commentary on the Apocalypse of St. John. Tübingen: Mohr Siebeck.

\section{RolOFF J}

1987. Die Offenbarung des Johannes. Zürich: Theologischer Verlag. Züricher Bibelkommentare 18 .

\section{SCHÜSSLER-FIORENZA E}

1981. Invitation to the Book of Revelation. New York: Doubleday.

\section{SICKENBERGER J}

1939. Die Johannesapokalypse. Bonn: Hanstein.

\section{SWETE H B}

1911. The Apocalypse of St John. The Greek text with introduction, notes and indices. London: MacMillan.

\section{THOMSON I H}

1995. Chiasmus in the Pauline Letters. Sheffield: JSOT Press. JSNTSS 111.

\section{VAN SCHAIK A P}

1971. De Openbaring van Johannes. Roermond: Romen.

\section{VANNI U}

1991. Liturgical dialogue as a literary form in the Book of Revelation. NTS 37:348-71.

\section{WITHERINGTON B}

2003. Revelation. Cambridge: Cambridge University Press.

Keywords

Revelation 6:12-17

Sixth Seal

Literary techniques

Exegesis

Setting
Trefwoorde

Openbaring 6:12-17

Sesde seël

Literêre tegnieke

Eksegese

Situering 